\title{
PENINGKATAN HASIL BELAJAR SISWA PADA MATA PELAJARAN BAHASA INDONESIA DENGAN MENGGUNAKAN MODEL PEMBELAJARAN KOOPERATIF TIPE TPS (THINK PAIR SHARE)MATERI PERCAKAPAN KELAS V SD NEGERI 104273 CILAWAN KECAMATAN PANTAI CERMIN T.P 2017-2018
}

\section{OLEH: \\ WAHYU SRI REJEKI RAJAGUKGUK (PGSD FKIP UNIVERSITAS KATOLIK SANTO THOMAS SU)}

\begin{abstract}
This study aims to: (1) to improve student learning outcomes in Indonesian language lesson using cooperative model model of TPS (Think Pair Share) class V SD Negeri 104273 Cilawan Kecamatan Pantai Cermin T.P 20172018. To find out how the implementation of learning by using cooperative cooperative learning model of TPS type (Think Pair Share) on Indonesian lesson in class V SD Negeri 104273 Cilawan T.P 2017-2018. Subjects in carrying out the action in this study are researchers who work together with the homeroom as an observer, while the object in this study is the students of grade V SD Negeri 104273 Cilawan which amounted to 33 students consisting of 15 men and 18 women. Data collection techniques through observation of the results of learning tests and student learning activities. The results of this study showed an increase in student learning outcomes on the subjects of Bahasa Indonesia class V conversational materials SD Negeri 104273 Cilawan. This is evident from the results of research conducted on the pretest of students who got the complete value of 7 students or $21.21 \%$ while the students who did not complete as many as 26 people or 78.79. Then continued the research on the first cycle of students who got the complete value of 14 students or $42.42 \%$ while students who do not complete as many as 19 students or $57.58 \%$, then there is an increase in the cycle I compared to the pretest. However, it has not met the completeness category that has been specified. Then proceeded on the second cycle of students who received a complete score of 28 students or $84,85 \%$ while students who are not complete as many as 5 students or $15.15 \%$, then there is an increase in cycle II compared to cycle I and has fulfilled the mastery already specified. Furthermore, teacher activity in observation cycle I obtained an average of $60 \%$ and in cycle II increased to $84 \%$. While the student activity on the learning process memeproleh average of $64 \%$ and on the second cycle has increased $88 \%$. Thus, it is concluded that by using cooperative learning model of TPS type (Think Pair Share) on Indonesian Language conversation material in class V SD Negeri 104273 Cilawan can improve student learning outcomes. Therefore it is suggested for the next learning to use cooperative model of TPS type (Think Pair Share) so that student learning result can be increased.
\end{abstract}

Keywords: Student Learning Result, Indonesian Language Subject TPS Type Co-operative Model (Think Pair Share). 


\section{PENDAHULUAN}

\section{Latar Belakang Masalah}

Pendidikan tidak dapat dipisahkan dari kehidupan manusia, setiap manusia memiliki hak mengayam pendidikan. Pendidikan merupakan bagian dari proses kehidupan bernegara. Kualitas susatu negara dapat dilihat dari kualitas sumber daya manusia yang dimiliki oleh negara tersebut. Salah satu upaya untuk meningkatkan kualitas sumber daya manusia yakni dengan cara memperbaiki mutu pendidikan. Masalah yang sering dihadapi dunia pendidikan saat ini adalah masalah lemahnya pelaksanaan proses pembelajaran yang diterapkan para guru di sekolah. Proses pembelajaran yang terjadi selama ini kurang mampu mengembangkan kemampuan berpikir peserta didik. Pelaksanaan proses pembelajaran yang berlangsung di kelas hanya diarahkan pada kemampuan siswa untuk menghafal informasi, otak siswa dipaksa hanya untuk mengingat dan memperbanyak berbagai informasi tanpa dituntut untuk memahami informasi yang diperoleh untuk menghubungkannya dengan situasi dalam kehidupan seharihari (Susanto, 2013: 165).

Proses pembelajaran terjadi apabila di dalamnya terdapat interaksi antara berbagai komponen pembelajaran. Komponen-komponen pembelajaran itu dapat dikelompokkan dalam tiga kategori utama, yaitu guru, isi atau materi pembelajaran, dan siswa. Dalam menjalankan proses pembelajaran di sekolah guru mempunyai peranan penting dalam melaksanakan dan menyajiakan pembelajaran yang efektif dan efesien. Proses pembelajaran yang efektif dan efisien dapat tercapai apabila persiapan guru sudah mantap dan terencana dengan baik. Dengan terciptanya pembelajaran yang efektif dan efesien diharapkan dapat meningkatkan hasil belajar siswa menjadi lebih baik. Pembelajaran yang efektif bukan hanya proses belajar mengajar yang terfokus pada hasil yang dicapai siswa, akan tetapi bagaimana proses pembelajaran yang efektif memberikan perubahan perilaku serta mengaplikasikannya dalam kehidupan itu sendiri.

Terdapat beberapa faktor yang dapat mempengaruhi kegiatan sistem kegiatan pembelajaran diantaranya faktor guru, faktor siswa dan alat dan media yang tersedia, serta faktor lingkungan (Sanjaya, 2011:52). Faktor-faktor tersebut dapat mempengaruhi keberhasilan belajar, sehingga terjadi perbedaan hasil belajara setiap siswa. Dalam dunia pendidikan, peranan guru tidak dapat dipisahkan dari proses pembelajaran. Oleh karena itu, guru diharapkan mampu memilih dan menggunakan jenis-jenis pendekatan, strategi pembelajaran, model pembelajaran, metode mengajar, serta media yang sesuai dengan tingkat pemahaman siswa. Banyak materi yang akan dipelajari saat menduduki bangku Sekolah Dasar (SD). Materi-materi yang diajarkan sesuai dengan tingkat usia anak-anak. Semua materi yang dipelajari di Sekolah Dasar (SD) akan dimasukkan ke dalam beberapa mata pelajaran yang telah disesuaikan.

Standar proses pendidikan dapat diartikan sebagai suatu bentuk teknis yang merupakan acuan atau kriteria yang dibuat secara terencana atau didesain dalam pelaksanaan pembelajaran. Hal ini sesuai yang dikemukakan oleh Sanjaya (2011:4) bahwa "standar proses pendidikan adalah standar nasioal pendidikan untuk mencapai standar kompetensi lulusan (Peraturan Pemerintah No. 19 Tahun 
2005 Bab 1 Pasal 1 Ayat 6)". Secara sederhana, yang dimaksud dengan hasil belajar siswa adalah kemampuan yang diperoleh anak setelah melalui kegiatan belajar. Karena belajar itu sendiri merupakan suatu proses dari seseorang yang berusaha untuk memperoleh suatu bentuk perubahan perilaku yang relatif menetap. Dalam kegiatan pembelajaran atau kegiatan instruksional, biasanya guru menetapkan tujuan belajar. Anak yang berhasil dalam belajar adalah yang berhasil mencapai tujuan-tujuan pembelajaran atau tujuan instruksional.

Dalam kegiatan pembelajaran ada banyak mata pelajaran yang dipelajari peserta didik. Salah satu kegiatan pendidikan belajar mengajar yang diberikan di lembaga pendidikan formal (sekolah) yaitu pelajaran Bahasa Indonesia. Permendiknas No. 22 Tahun 2006 mengatur tentang Standar isi tingkatan kelas di SD/MI berisi enam (6) mata pelajaran yaitu, Pendidikan Kewarganegaraan (PKn), Bahasa Indonesia, Matematika, Ilmu Pengetahuan Alam (IPA), Ilmu Pengetahuan Sosial (IPS), dan Seni Budaya dan Keterampilan (SBK).

Bahasa Indonesia merupakan salah satu disiplin ilmu yang dapat meningkatkan keterampilan berbahasa peserta didik, meningkatkan rasa percaya diri, dan meningkatkan kemampuan berpikir serta berargumentasi. Dalam kehidupan sehari-hari, kita menyampaikan sesuatu menggunakan bahasa. Bahasa tidak bisa dilepaskan dari kehidupan manusia sehari-hari. Bahasa merupakan alat untuk berfikir dan belajar, serta menyampaikan sesuatu yang terlintas di dalam hati. Proses pendidikan di sekolah adalah melalui proses pembelajaran. Sanjaya (2011:11) mengemukakan bahwa "Salah satu masalah yang dihadapi dunia pendidikan kita adalah masalah lemahnya proses pembelajaran". Dengan adanya bahasa memungkinkan peserta didik untuk berpikir secara abstrak. Bahasa dapat kita artikan sebagai rangkaian bunyi yang mempunyai makna tertentu. Dengan bahasa, kita dapat menyatakan kegembiraan, kesedihan, harapan, dan perasaanperasaan lainnya. Dengan bahasa, perasaan-perasaan itu dapat dimengerti orang lain dengan mudah. Pembelajaran bahasa diharapkan membantu peserta didik mengenal dirinya, kebudayaan dan budaya orang lain, memberikan suatu gagasan, perasaan dan berpartisipasi dalam masyarakat yang menggunakan bahasa tersebut, dengan menemukan dan menggunakan keterampilan yang terdapat dalam dirinya. Keterampilan berbahasa menekankan pada empat aspek, yakni menyimak, berbicara, membaca dan menulis. Proses pembelajaran terjadi apabila di dalamnya terjadi interaksi antara berbagai komponen pembelajaran. Menurut Samiati dan Asra (2016:3) "Komponen-komponen itu dapat dikelompokkan ke dalam tiga kategori utama, yaitu; guru, isi atau materi pembelajaran, dan siswa".

Berdasarkan data yang saya peroleh dari guru kelas $\mathrm{V}$ terungkap bahwa hasil belajar Bahasa Indonesia siswa kelas V SD Negeri 104273 Cilawan Kecamatan Pantai Cermin masih tergolong rendah. Berdasarkan observasi yang peneliti lakukan menunjukan bahwa hasil belajar Bahasa Indonesia siswa masih rendah. Pada mata pelajaran Bahasa Indonesia masih didominasi oleh guru dengan menggunakan metode ceramah dan kegiatan belajar mengajar lebih berpusat pada guru yang mengakibatkan hasil belajar siswa rendah sehingga belum tercapai hasil belajar siswa yang diinginkan serta belum menunjukkan hasil optimal dengan Kriteria Ketuntasan Minimal (KKM) yaitu 70. Hal ini dapat dilihat pada hasil belajar ulangan harian mata pelajaran Bahasa Indonesia kelas V SD Negeri 104273 Cilawan Kecamatan Pantai Cermin T.P 2016/2017 adalah dari 33 siswa 
jumlah siswa masih 11 siswa yang memenuhi KKM yaitu jumlah siswa yang berhasil perjumlah seluruh siswa dikali seratus persen dan hasilnya sebesar (33\%) adalah siswa yang sudah memenuhi kriteria ketuntasan, sedangkan jumlah siswa yang tidak memenuhi KKM adalah sekitar 22 siswa (67\%) untuk mata pelajaran Bahasa Indonesia dikelas V SD Negeri 104273 Cilawan Kecamatan Pantai Cermin.

Oleh karena itu, proses belajar mengajar memerlukan strategi pembelajaran yang menyenangkan, mudah dipahami siswa, dan menempatkan siswa sebagai subjek belajar yang tidak hanya menerima secara pasif apa yang disampaikan oleh guru. Guru harus menempatkan siswa sebagai insan yang secara alami memiliki pengalaman, pengetahuan, keinginan, dan pikiran yang dapat dimanfaatkan untuk belajar, baik secara individu maupun kelompok. Strategi pembelajaran yang dipilih guru hendaknya melibatkan siswa berperan aktif dalam proses belajar agar siswa mempunyai keyakinan bahwa dirinya mampu belajar sehingga dapat meningkatkan kemampuan berbicaranya untuk menyampaikan pendapatnya dalam kelas. Hal ini seperti yang dikemukakan oleh Syah (2015:90) "Secara umum belajar dapat dipahami sebagai tahapan perubahan seluruh tingkah laku individu yang relatif menetap sebagai hasil pengalaman dan interaksi dengan lingkungan yang melibatkan proses kognitif".

Siswa merasa malu dan takut untuk berdiri dan berbicara dihadapan teman sekelasnya. Bahkan tidak jarang beberapa siswa berkeringat dingin, gugup sehingga lupa segalanya jika berdiri di depan kelas untuk berbicara. Hal tersebut sebagaimana dikemukakan menurut Sanjaya (2011:52) "Terdapat beberapa faktor yang dapat mempengaruhi kegiatan sistem pembelajaran, diantaranya faktor guru, faktor siswa, alat dan media yang tersedia, serta faktor lingkungan". Jika mempunyai ide, siswa lebih memilih diam. Suara siswa saat bercanda dengan temannya sangat nyaring, namun ketika saat berbicara di depan kelas justru sebaliknya bersuara lemah dan bahkan cenderung tergesa-gesa. Kondisi ini diakibatkan rendahnya penguasaan siswa akan topik yang dibahas sehingga siswa tidak mampu memfokuskan hal-hal yang diucapkan. Akibatnya, arah pembicaraan menjadi kurang jelas dan inti dari pembahasan tersebut tidak tersampaikan.

Adapun pemecahan masalah yang tepat untuk meningkatkan hasil belajar siswa dalam proses belajar mengajar, salah satu solusinya seorang guru dituntut kemampuannya untuk menggunakan metode pembelajaran secara tepat agar tercipta kondisi pembelajaran yang menyenangkan bagi siswa dan materi tersampaikan secara efektif sehingga tujuan pembelajaran yang diharapkan dapat tercapai dengan optimal. Salah satu strategi yang paling tepat adalah strategi pembelajaran think pair share. Strategi pembelajaran think pair share adalah strategi pembelajaran yang memberi kesempatan kepada setiap siswa untuk menunjukkan partisipasi kepada orang lain. Langkah-langkah strategi pembelajaran kooperatif tipe think pair share yang akan diterapkan dalam proses belajar mengajar adalah dengan meminta siswa berfikir secara individual, selanjutnya siswa belajar dari teman yang satu, ke teman yang lain, dan saling menyampaikan idenya untuk didiskusikan sebelum disampaikan di depan kelas.

Dengan strategi pembelajaran tersebut diharapkan siswa akan dapat mengatasi rasa malu dan takut yang selalu mengganggu kelancaran berbicara dalam proses diskusi kelompok atau saat berbicara di depan teman-temannya. 
Strategi ini memberi kesempatan kepada setiap siswa untuk menunjukkan partisipasi kepada orang lain. Siswa dilatih untuk mengembangkan keterampilan berfikir dan menjawab dalam komunikasi antara satu dengan yang lain, saling membantu dalam kelompok kecil. Hal ini sebagaimana yang dikemukakan Lie (2010:57) bahwa, "think pair share adalah pembelajaran yang memberi siswa kesempatan untuk bekerja sendiri dan bekerjasama dengan orang lain."

Atas dasar inilah peneliti tertarik untuk mengadakan penelitian dengan judul: "Peningkatan Hasil Belajar Siswa Pada Pelajaran Bahasa Indonesia Dengan Menggunakan Model Pembelajaran Kooperatif Tipe Think Pair Share (TPS) Kelas V SD 104273 Cilawan Kecamatan Pantai Cermin T.P 2017/2018.

\section{Identifikasi Masalah}

Berdasarkan latar belakang masalah di atas, maka dapat diidentifikasi masalah sebagai berikut:

1. Penggunaan metode yang monoton

2. Guru kurang melibatkan peserta didik secara aktif sehingga perhatian peserta didik berkurang.

3. Kurangnya peran siswa dalam mengikuti pembelajaran

4. Guru menekankan belajar dengan menghapal bukan dengan pemahaman

5. Siswa tidak termotivasi dalam belajar

\section{Pembatasan Masalah}

Mengingat berbagai keterbatasan yang dimiliki oleh peneliti, dan tidak memungkinkan setiap masalah yang ada untuk diteliti, maka peneliti membatasi permasalahan Peningkatan Hasil Belajar Siswa Pada Pelajaran Bahasa Indonesia Materi Percakapan Dengan Menggunakan Model Pembelajaran Kooperatif Tipe Think Pair Share (TPS) Kelas V SD Negeri 104273 Cilawan Kecamatan Pantai Cermin T.P 2017/2018.

\section{Perumusan Masalah}

Berdasarkan latar belakang, identifikasi dan batasan masalah yang telah dikemukakan pada bagian terdahulu, maka pokok permasalahan yang harus diselesaikan oleh peneliti, dengan merumuskan permasalahan sebagai berikut :

1. Bagaimana peningkatan hasil belajar siswa dengan menggunakan model pembelajaran kooperatif tipe TPS (Think Pair Share)?

2. Bagaimana pelaksanaan pembelajaran dengan menggunakan model pembelajaran kooperatif tipe think pair share materi percakapan pada pelajaran Bahasa Indonesia di kelas V SD Negeri 104273 Cilawan tahun pelajaran 2017/2018?

\section{Tujuan Penelitian}

Adapun tujuan penelitian ini adalah:

1. Untuk mengetahui peningkatan hasil belajar siswa pada pelajaran Bahasa Indonesia dengan menggunakan model pembelajaran kooperatif tipe TPS (Think Pair Share) materi percakapan kelas V SD Negeri 104273 Cilawan Kecamatan Pantai Cermin T.P 2017/2018.

2. Untuk mengetahui bagaimana pelaksanaan pembelajaran dengan menggunakan model pembelajaran kooperatif tipe TPS (Think Pair Share) pada pelajaran Bahasa Indonesia di kelas V SD Negeri 104273 Cilawan tahun pelajaran 2017/2018.

\section{Manfaat Penelitian}

Volume: 1 No. 1 Juli 2018

JURNAL ILMIAH AQUINAS TERBIT JULI DAN JANUARI SETIAP TAHUNNYA 
Adapun hasil-hasil dari pelaksanaan penelitian ini, diharapkan dapat memberikan manfaat yaitu:

\section{Manfaat Teoritis}

Hasil penelitian ini dapat memperkaya ilmu pengetahuan khususnya kajian mengenai pentingnya peranan peserta didik khususnya pada mata pelajaran Bahasa Indonesia.

\section{Manfaat Praktis}

\section{a. Bagi siswa}

Untuk meningkatkan keaktifan dan respon peserta didik dalam pembelajaran. Melalui penggunaan strategi think pair share siswa menjadi berani berbicara dalam hal menegeluarkan pendapat atau perasaan berkaitan dengan materi pelajaran. Mempermudah peserta didik dalam menemukan konsep melalui praktek langsung sehingga hasil belajar siswa meningkat

\section{b. Bagi guru}

Guru menjadi lebih profesional sehingga menambah rasa percaya diri yang tinggi dalam melaksanakan pembelajaran

\section{c. Bagi pihak sekolah}

Sebagai bahan masukan atau evaluasi guna meningkatkan mutu dan kualitas pendidikan sekolah. Pembelajaran di sekolah lebih efektif dan efisien

\section{d. Bagi peneliti}

Menambah pengalaman dan pengetahuan peneliti dalam menerapkan model think pair share dalam melaksanakan penelitian.

\section{METODOLOGI PENELITIAN Pendekatan dan Metode Penelitian}

Pendekatan dalam penelitian ini adalah pendekatan campuran yaitu dengan mengkombinasikan dua pendekatan (kuantitatif dan kualitatif). Kemudian menindak lanjuti dengan wawancara atau observasi sejumlah individu untuk membantu menjelaskan lebih jauh statistik yang diperoleh. Penelitian yang dilaksanakan adalah Penelitan Tindakan Kelas, yaitu penelitian yang dilakukan untuk mencari suatu dasar pengetahuan praktis dalam rangka memperbaiki situasi yang dilakukan secara terbatas didalam kelas. Dengan menggunakan pendekatan campuran peneliti dapat memperoleh hasil-hasil statistik kuantitatif dari suatu sampel, kemudian menindaklanjutinya dengan mewawancarai atau observasi sejumlah individu untuk membantu menjelaskan lebih jauh hasil statistik yang diperoleh.

Metode atau jenis penelitian yang dilakukan merupakan Penelitian Tindakan Kelas (PTK) karena pada penelitian ini bertindak secara langsung dalam penelitian. Pemilihan metode ini didasari sebagai upaya peningkatan efektifitas pembelajaran yang berlangsung dalam tahap siklus. Penelitian Tindakan Kelas (PTK) bermula dari suatu perencanaan, pelaksanaan, pengamatan, dan refleksi. Penelitian ini bertujuan untuk meningkatkan hasil pembelajaran Bahasa Indonesia kelas V SD Negeri 104273 Cilawan dengan menggunakan pembelajaran tipe TPS tahun pembelajaran 2017/2018.

\section{Lokasi dan Jadwal Penelitian}

\section{Lokasi Penelitian}


Peneliti melakukan Penelitian Tindakan Kelas ini di Sekolah Dasar Negeri 104273 Cilawan Kecamatan Pantai Cermin. Peneliti memilih sekolah tersebut karena berdasarkan observasi dan data hasil belajar siswa menunjukan bahwa hasil belajar Bahasa Indonesia masih rendah. SD Negeri 104273 Cilawan adalah salah satu sekolah di Kecamatan Pantai Cermin terletak di Jl. Cilawan.

\section{Jadwal Penelitian}

Jadwal penelitian direncanakan pada semester ganjil tahun pelajaran 2017/2018 sebanyak 2 siklus.

\section{Subjek dan Objek Penelitian}

\section{Subjek Penelitian}

Subjek dalam penelitian ini adalah siswa kelas V SD Negeri 104273 Cilawan Kecamatan Pantai Cermin Tahun Pelajaran 2017/2018 pada semester 1 tahun ajaran 2017/2018, yang berjumlah 33 siswa.

\section{Objek Penelitian}

Objek penelitian ini adalah dengan mrnggunakan model pembelajaran kooperatif tipe TPS (Think Pair Share) dapat meningkatkan hasil belajar.

\section{Jenis dan Sumber Data}

\section{Jenis Data}

Jenis data yang diperoleh pada penelitian ini adalah data kuantitatif dan data kualitatif. Data kuantitatif dari penelitian ini adalah suatu proses menemukan pengetahuan yang menggunakan data berupa angka sebagai alat menemukan keterangan mengenai apa yang kita ketahui.

Data kualitatif dari penelitian ini adalah gejala-gejala untuk memahaminya tidak mudah dilakukan dengan menggunakan alat ukut, melainkan naluri dan perasaan.

\section{Sumber Data}

Sumber data merupakan subjek dari mana data dapat diperoleh. Sumber data penelitian ini adalah sumber data primer dan sekunder. Sumber data primer yaitu informan (orang) yang dapat memberikan informasi tentang data penelitian. Informan dalam penelitian ini peserta didik kelas V SD Negeri 104273 Cilawan yang terdiri dari 33 siswa. Hal ini menjadi pertimbangan untuk mengetahui sejauh mana keberhasilan siswa dalam pembelajaran yang diberikan tindakan dengan diterapkannya model pembelajaran kooperatif tipe think pair share.

Sumber data sekunder yaitu sumber yang tidak langsung memberikan data kepada pengumpul data. Sumber data tersebut adalah data hasil belajar yang dikumpulkan oleh orang lain yaitu data pendukung dalam penelitian ini kepala sekolah SD Negeri 104273 Cilawan. Jenis data sekunder yang digunakan dalam penelitian ini adalah: aktivitas, tempat atau lokasi, dan dokumentasi atau arsip.

\section{Teknik dan Alat Pengumpulan Data}

\section{Observasi}

Teknik observasi merupakan teknik pengumpulan data dengan melakukan pengamatan pada objek penelitian. Pada penelitian ini melibatkan peneliti dan guru sebagai observasi. Proses observasi dilakukan dengan mengacu pada pedoman observasi yang telah disusun. Aktivitas guru dan siswa diamatai untuk mendapatkan data kulitatif yaitu mengenai seberapa besar proses pembelajaran Bahasa Indonesia dengan menggunakan model kooperatif tipe think pair share 
dapat mempengaruhi aktivitas guru dan siswa dan apakah kegiatan yang dilakukan telah sesuai dengan yang direncanakan dalam RPP.

2.

Tes

Tes adalah alat yang digunakan untuk mengukur perkembangan atau kemajuan belajar peserta didik dengan cara pemberian soal. Teknik tes digunakan untuk mengetahui keberhasilan belajar siswa setelah melakukan pembelajaran.

\section{Uji Validitas dan Reliabilitas Instrumen}

\section{Uji Vadilitas Instrument}

Agar instrument yang dibuat oleh peneliti dapat dikatakan valid maka dilakukan uji vadilitas. Vadilitas dalam penelitian ini dilakukan dengan diuji dan diperiksa vadilitasnya, sehingga data tersebut dapat dipertanggung jawabkan. Untuk menjamin vadilitas ini maka semua pertanyaan disusun berdasarkan kajiankajian teori yang berkaitan dengan permasalahan. Cara yang digunakan untuk mengetahui tingkat vadilitas instrument penelitian ini adalah menggunakan rumus korelasi sebagai berikut:

$$
\mathrm{r}_{\mathrm{xy}}=\frac{n \sum x y-\sum x \sum y}{\sqrt{\left.\left(\ln \sum \mathrm{x}^{2}-\left(\sum x\right)^{2}\right), 1, \sum y^{2}-\left(\sum y\right)^{2}\right\}}}
$$

(Purwanto, $2014: 118$ )

Keterangan:

$r_{x y}=$ koefisien kolerasi antara $\mathrm{x}$ dan $\mathrm{y}$

$N=$ banyak peserta tes

$X=$ nilai hasil uji coba

$Y=$ rata-rata nilai siswa

Setelah diketahui koefisien kolerasi antar $\mathrm{X}$ dan $\mathrm{Y}$, selanjutnya adalah menginterpretasikan besarnya koefisien kolerasi dengan menggunakan kriteria sebagai berikut:

$0,800-1,000=$ Sangat tinggi

$0,0600-0,800=$ Tinggi

$0,400-0,600=$ Cukup

$0,200-0,400=$ Rendah

$0,000-0,200=$ Sangat rendah

1. Keputusan pengujian validitas instrumen adalah :

Item pernyataan dikatakan valid apabila r.hitung $>$ r.tabel pada taraf signifikasi $0,5 \%$.

2. Item pernyataan dikatakan tidak valid apabila r.hitung < r.tabel pada taraf signifikasi $0,5 \%$.

\section{Uji Reliabilitas Instrumen}

Setelah diketahui validitas soal maka dilakukan kembali dengan reliabilitas soal. Reliabilitas soal merupakan ukuran yang menyatakan tingkat keajengan kekonsistenan suatu soal tes. Untuk mengukur tingkat keajengan soal ini digunakan perbandingan alpha crombach's rumus yang digunakan dinyatakan dengan 
Reliabilitas alat penilaian adalah ketetapan alat tersebut dalam menilai apa yang dinilainya. Artinya kapan pun alat penilaian tersebut digunakan akan memberikan hasil yang relatif sama Sudjana (2009: 16). Untuk menguji reliabilitas tes pada penelitian ini yang digunakan adalah KR-20 dengan rumus sebagai berikut:

$\mathrm{r}_{11}=\left[\frac{n}{n-1}\right]\left[1-\frac{\sum s_{1}^{2}}{s_{1}^{2}}\right]$ Jihad dan Haris (2012 :

180)

Keterangan:

$\mathrm{r}_{11} \quad$ : Reliabilitas yang dicari

$\mathrm{n} \quad$ : Banyaknya butir soal

$\sum S_{1}^{2} \quad$ Jumlah varians skor tiap-tiap item

$S_{1}^{2} \quad$ : Varians skor total

Interpretasi terhadap nilai koefisien korelasi $r_{11}$ digunakan kriteria sebagai berikut:

$r_{11} \leq 0,20 \quad$ : reliabilitas sangat rendah

$0,20<r_{11} 0,40 \quad:$ reliabilitas rendah

$0,40<r_{11} 0,70 \quad:$ reliabilitas sedang

$0,70<r_{11} 0,90 \quad$ : reliabilitas tinggi

$0,90<r_{11} 1,00 \quad$ : reliabilitas sangat tinggi

\section{Analisis Data}

Analisis data digunakan untuk mengetahui berhasil atau tidaknya tindakan yang dilakukan dalam penelitian. Sesuai dengan tujuan penelitian, maka analisi data yang digunakan adalah :

\section{Hasil Pelaksanaan Pembelajaran}

a. Aktivitas Guru

Untuk mengetahui proses pelaksanaan pembelajaran aktivitas guru digunakan rumus:

$\mathrm{HP}=\frac{\text { jumlah hasil belajar }}{\text { jumlah butîr pengamatan }} \times 100 \%$

(Piet, 2013:61)

Kriteria Penilaian Dalam Pelaksanaan Pembelajaran Aktivitas Guru

Adalah Sebagai Berikut :

$\mathrm{A}=81-100 \%=$ Baik Sekali

$\mathrm{B}=61-80 \%=$ Baik

$\mathrm{C}=41-60 \% \quad=$ Cukup

$\mathrm{D}=21-40 \% \quad=$ Kurang

$\mathrm{E}=0-20 \% \quad=$ Sangat Kurang

b. Aktivitas Siswa

Rumus penilaian aktivitas siswa sebagai berikut:

Nilai siswa $=\frac{\text { skor perolehan }}{\text { skor maksimum }} \times 100 \% \quad$ (Jihad dah haris, 2013:130)

Kriteria penilaian aktivitas siswa dalam pelaksanaan pembelajaran menurut jihad dan haris (2013:131) sebagai berikut:

Nilai $10-29 \%=$ Sangat kurang 
Nilai $20-49 \%=$ Kurang

Nilai $50=69 \%=$ Cukup

Nilai $70-89 \%=$ Baik

Nilai $90-100 \%=$ Sangat baik

2. Ketuntasan Belajar Siswa

a. Ketuntasan Individual

Siswa yang dikatakan tuntas belajarnya (ketuntasan individual) yaitu apabila siswa memperoleh hasil belajar yang mencapai KKM yang ditentukan oleh sekolah yaitu 70. Untuk memperoleh ketuntasan belajar siswa (individu) dapat dihitung dengan menggunakan rumus sebagai berikut.

$$
K \mathrm{~B} \frac{T}{T} \times 100 \%
$$

(Trianto, 2011:241)

Keterangan:

$\mathrm{KB}=$ Ketuntasan Belajar

$\mathrm{T}$ =Jumlah skor yang diperoleh siswa

$\mathrm{Tt}=$ Jumlah skor total

Hasil perhitungan diseusaikan dengan criteria ketuntasan belajar siswa yang dikelompokkan dalam dua kategori tuntas dan tidak tuntas. Dengan kriteria sebagai berikut:

Hasil penghitungan disesuaikan dengan criteria ketuntasan belajar siswa yang dikelompokkan ke dalam dua kategori tugas dan tidak tuntas. Dengan criteria sebagai berikut:

$$
\begin{aligned}
& \geq 70=\text { Tuntas } \\
& \leq 70=\text { Tidak Tuntas }
\end{aligned}
$$

\section{b. Ketuntasan Klasikal}

Suatu kelas dikatakan tuntas belajarnya (ketuntasan klasikal) jika dalam kelas tersebut dapat $\geq 85 \%$ siswa yang telah tuntas belajarnya dari nilai KKM yang ditentukan sekolah yaitu70.

2016:41)

$$
\mathrm{P}=\frac{\text { Isiswa yang tuntas belajar }}{\text { Esiswa }} \mathrm{X} 100 \% \quad \text { (Aqib Dkk, }
$$

Tabel 3.7 Kriteria Tingkat Keberhasilan Belajar Siswa Dalam \%

\begin{tabular}{|c|c|}
\hline Tingkat keberhasilan & Arti \\
\hline$>80 \%$ & Sangat tinggi \\
\hline $60-76 \%$ & Tinggi \\
\hline $40-59 \%$ & Sedang \\
\hline $20-39 \%$ & Rendah \\
\hline$<20 \%$ & Sangat rendah \\
\hline
\end{tabular}

Hasil analisis ini digunakan sebagai bahan refleksi untuk melaksanakan perencanaan lanjut dalam siklus berikutnya. Hasil analisis juga dijadikan sebagai bahan refleksi dalam memperbaiki rancangan pembelajaran.

\section{c. Mencari Nilai Rata-Rata}

Peneliti menjumlahkan nilai yang diperoleh siswa kemudian dibagikan dengan jumlah siswa tersebut sehingga diperoleh nilai rata-rata. Nilai rata-rata diperoleh dengan menggunakan rumus.

$$
\mathrm{X} \frac{\sum x}{\Sigma y}
$$

Keterangan : 
$\mathrm{X}=$ Nilai rata-rata

$\sum \mathrm{X}=$ Jumlah semua nilai siswa

$\sum \mathrm{N}=$ jumlah siswa

\section{Indikator Kinerja Penelitian}

Indikator kinerja yang ingin diperoleh dalam penelitian tindakan kelas ini meningkatnya hasil belajar Bahasa Indonesia pada siswa kelas V SD Negeri 104273 Cilawan setelah menerapkan model pembelajaran kooperatif tipe Think Pair Share sebagai ukuran keberhasilan pelaksanaan peneliti tindakan kelas ini adalah jika indikator keberhasilan hasil belajar secara klasikal minimal 75 dari jumlah siswa mencapai KKM=70 dengan cara pengukuran adalah dengan hasil tes dalam mengerjakan soal yang telah ditentukan oleh peneliti.

\section{Produser Penelitian}

Pelaksanaan proses penelitian disesuaikan dengan rencana yang telah dibuat sebelumnya. Pelaksanaan penelitian terdiri dari proses pembelajaran, evaluasi, dan refleksi pada setiap siklus.

\section{HASIL PENELITIAN DAN PEMBAHASAN Pembahasan Hasil Temuan}

Pada bahasan ini akan diuraikan hasil temuan dalam penelitian diperoleh melalui hasil observasi dan refleksi pada setiap siklusnya. Pada saat pelaksanaan pembelajaran Bahasa Indonesia dengan menerapkan model pembelajaran kooperatif tipe think pair share pada siswa V SD Negeri 104273 Cilawan Kecamatan Pantai Cermin dalam materi percakapan diperoleh temuan-temuan berdasarkan hasil observasi yang dilaksanakan selama proses pembelajaran.

\section{Hasil Belajar Siswa}

Pelaksanaan tindakan ini peneliti merancang dalam pembelajaran Bahasa Indonesia pada materi percakapan. Sebelum masuk pada siklus I peneliti melakukan tes awal (Pretest) untuk mengetahui sejauh mana pengetahuan dan kemampuan siswa dalam memahami materi percakapan. Dari hasil analisis pada Pretest dapat dinyatakan bahwa kemampuan siswa masih dibawah $75 \%$ dengan rata-rata nilai 51,82 sehingga mempengaruhi hasil belajar yang maksimal. Untuk mengatasi hal ini guru menerapkan model pembelajaran kooperatif tipe think pair share, dimana proses pembelajaran berdasarkan pasangan. Model pembelajaran kooperatif tipe think pair share ini sangat efektif selain melatih siswa berfikir untuk mengeluarkan pendapatnya, model ini juga melatih siswa untuk berkerja sama dengan teman-temannya.

Pada siklus I diperoleh tingkat ketuntasan belajar siswa sebesar 42,42\% dengan rata-rata 62,72. Melihat hasil ketuntasan belajar siswa pada siklus I siswa juga masih belum memahami materi percakapan. Penelitian tindakan ini belum mencapai tingkat keberhasilan dalam meningkatkan hasil belajar siswa hanya pada siklus I. Oleh karena itu, dari data yang diketahui pada siklus I menjadi panduan untuk memperbaiki hasil belajar siswa dengan merancang pelaksanaan pembelajaran yang lebih menyenangkan dan seoptimal mungkin untuk mencapai hasil belajar yang maksimal. Pada siklus II, peneliti lebih fokus dalam pemberian materi percakapan untuk merancang kembali model pembelajaran kooperatif tipe think pair share yang dapat membuat siswa menjadi aktif, menyenangkan, semangat belajar sehingga mendapat ketuntasan belajar yang maksimal. Setelah 
dilakukan evaluasi diakhir pertemuan diperoleh peningkatan hasil belajar siswa dengan nilai rata-rata 78,49 dan ketuntasan belajar yaitu sebesar 84,85\%.

Dengan demikian dapat disimpulkan bahwa terjadi peningkatan hasil belajar siswa yang dilihat dari ketuntasan belajar siswa dimulai dari Prates hingga ke siklus II atau dapat dikatakan melalui penerapan model pembelajaran kooperatif tipe think pair share dapat meningkatkan hasil belajar siswa terhadap materi percakapan di kelas V SD Negeri 104273 Cilawan Kecamatan Pantai Cermin T.P 2017/2018.

\section{Hasil Observasi}

Berdasarkan data hasil pengamatan (observasi) yang dilakukan pada aktivitas guru dan aktivitas siswa pada siklus I dan siklus II. Berikut penjabaran observasi sebagai berikut:

\section{Hasil Observasi Aktivitas Guru}

Berdasarkan hasil pengamatan (observasi) aktivitas guru pada setiap siklus, keterampilan guru dalam menjelaskan materi kurang baik dan kurang menguasai kelas pada saat pembelajaran yang tampak pada pertemuan pertama di siklus I. Pada siklus I dan siklus II ada peningkatan kegiatan guru selama proses pembelajaran berlangsung selama siklus diterapkan di dalam kelas.

1. Siklus I observasi guru hanya sebesar $60 \%$

2. Siklus II terjadi peningkatan pada observasi guru sebesar $84 \%$.

Hal ini menunjukkan bahwa sudah ada perubahan yang terjadi pada kegiatan guru di dalam kelas hingga hasil pengamatan pada kegiatan guru mengalami peningkatan dari kategori cukup menjadi baik sekali.

\section{Hasil Observasi Aktivitas Siswa}

Berdasarkan hasil pengamatan (observasi) aktivitas siswa pada setiap siklus, kemampuan siswa dalam memahami materi kurang, siswa kurang aktif pada saat pembelajaran, kemampuan berpikir siswa dalam mencari jawaban masih kurang dan interaksi antar siswa kurang. Hal ini sangat tampak pada pertemuan pertama di siklus I. Dari kegiatan aktivitas siswa yang dinilai sebanyak 2 indikator setiap siklusnya dan observer mengamati setiap indikator dengan menyesuaikan kegiatan siswa selama proses pembelajaran berlangsung. Pada siklus I dan siklus II ada peningkatan kegiatan siswa selama proses pembelajaran berlangsung selama siklus diterapkan di dalam kelas.

1. Siklus I observasi siswa hanya sebesar $64 \%$

2. Siklus II terjadi peningkatan pada observasi siswa sebesar $88 \%$.

Hal ini menunjukkan bahwa sudah ada perubahan yang terjadi pada diri siswa ketiaka mengikuti pembelajaran di dalam kelas dan siswa juga terlibat aktif dalam pembelajaran sehingga hasil pengamatan pada kegiatan siswa mengalami peningkatan dari kategori cukup menjadi baik sekali.

\section{PENUTUP Simpulan}

Berdasarkan deskripsi dan pembahasan hasil penelitian yang telah dipaparkan pada bab sebelumnya, maka dapat diperoleh beberapa kesimpulan sebagai berikut:

1. Dengan menggunakan model pembelajaran kooperatif tipe think pair share dapat meningkatkan hasil belajar siswa dalam menyelesaikan soal-soal 
pilihan berganda pada pelajaran Bahasa Indonesia materi percakapan di kelas V SD Negeri 104273 Cilawan Kecamatan Pantai Cermin. Model pembelajaran kooperatif tipe think pair share dapat membuat siswa menjadi aktif, kreatif dan mampu menyelesaikan permasalahan yang diajukan.

2. Dengan menggunakan model pembelajaran kooperatif tipe think pair share dapat meningkatkan keaktifan siswa dalam belajar yang dapat dilihat peningkatannya dalam observasi aktivitas siswa dan kemampuan guru dalam kegiatan pembelajaran sesuai dengan langkah-langkah pembelajaran yang disusun di dalam Rencana Pelaksanaan Pembelajaran (RPP) yang dapat dilihat peningkatannya dalam observasi kegiatan aktivitas guru. Hasil observasi aktivitas guru pada siklus I dengan persentase $60 \%$ sedangkan pada siklus II mengalami peningkatan dengan jumlah observasi dengan persentase $84 \%$ dan hasil observasi siswa pada siklus I dengan persentase $64 \%$, sedangkan pada siklus II mengalami peningkatan dengan persentase $88 \%$.

\section{Implikasi}

Pelaksanaan tindakan dilakukan di kelas V SD Negeri 104273 Cilawan Kecamatan Pantai Cermin, telah membawa perubahan yang berarti bagi proses belajar mengajar di kelas. Guru lebih memahami karakteristik siswa yang heterogen. Pelaksanaan tindakan ini peneliti merancang dalam pembelajaran Bahasa Indonesia pada materi percakapan. Penelitian ini memberikan suatu gambaran yang jelas bahwa keberhasilan proses pembelajaran tergantung pada beberapa faktor antar lain yaitu berasal dari pihak guru, siswa, model pembelajaran bahkan media yang digunakan oleh guru. Kemampuan guru dalam mengembangkan materi, menyampaikan materi, mengelola kelas, dan memilih serta mengimplementasikan model pembelajaran yang sesuai dengan materi pembelajaran.

Pembelajaran Bahasa Indonesia dengan model pembelajaran kooperatif tipe think pair share dapat dijadiakan sebagai bahan acuan untuk mengadakan penelitian selanjutnya dari sudut permasalahan yang berbeda. Selain itu dapat diimplementasikan sebagai bahan kajian pendekatan pembelajaran bagi guru untuk diterapkan di SD Negeri 104273 Cilawan Kecamatan Pantai Cermin sebagai alternatif model pembelajaran pada mata pelajaran lainnya selain Bahasa Indonesia. Berdasarkan dari hasil penelitian dan kesimpulan, maka peneliti menyampaikan beberapa implikasi sebagai berikut.

1. Bagi siswa, pembelajaran dengan menggunakan model pembelajaran kooperatif tipe think pair share ternyata mampu meningkatkan hasil belajar siswa terhadap materi percakapan. Hal ini terbukti dengan peningkatan ratarata nilai prestasi belajar siswa setiap siklusnya.

2. Bagi guru, pembelajaran melalui model pembelajaran kooperatif tipe think pair share dalam kegiatan pembelajaran Bahasa Indonesia bisa dijadikan alternatif pilihan pembelajaran dalam upaya meningkatkan hasil belajar siswa.

3. Bagi sekolah, penerapan model pembelajaran kooperatif tipe think pair share yang dapat meningkatkan hasil belajar siswa dapat digunakan sebagai salah satu cara untuk meningkatkan mutu sekolah sebagai pembanding dengan sekolah lain secara umum. 
4. Bagi peneliti, dengan menggunakan model pembelajaran kooperatif tipe think pair share dapat menambah pengalaman dan pengetahuan peneliti dalam melakukan penelitian.

\section{Keterbatasan Penelitian}

Dalam penelitian ini terdapat keterbatasan-keterbatasan yang diharapkan akan membuka kesempatan bagi peneliti lainnya untuk melakukan penelitian sejenis yang akan berguna bagi perluasan wawasan keilmuan. Diantara keterbatasan-keterbatasan itu adalah sebagai berikut:

1. Penelitian ini hanya dilakukan dalam waktu penelitian yang relatif sangat singkat, ternyata akan berdampak pada hasil yang dicapai belum maksimal.

2. Subjek dari penelitian ini hanya berasal dari SD Negeri 104273 Cilawan Kecamatan Pantai Cermin sehingga hasil penelitian belum tentu sesuai dengan sekolah lain atau daerah lain yang memiliki karakteristik berbeda.

3. Penelitian ini hanya terbatas pada penerapan model pembelajaran kooperatif tipe think pair share untuk meningkatkan hasil belajar Bahasa Indonesia. Banyak faktor yang mungkin saja berpengaruh terhadap hasil belajar siswa, seperti sikap terhadap guru, lingkungan sekolah dan sebagainya. Dengan demikian kondisi-kondisi itu bisa saja ikut dalam mempengaruhi hasil belajar Saran siswa pada pembelajar Bahasa Indonesia.

Berdasarkan kesimpulan diatas, maka penulis memberikan saran yakni sebagai berikut:

1. Kepada siswa khususnya siswa kelas V SD Negeri 104273 Cilawan Kecamatan Pantai Cermin diharapkan lebih giat belajar agar hasil belajar siswa dapat meningkat sesuai dengan yang diharapkan, membangun pola interaksi dan kerjasama yang baik kepada sesama siswa maupun guru, supaya lebih aktif, kreatif serta giat dalam mengikuti pelajaran sehingga hasil belajar dapat tercapai dengan baik.

2. Sebagai bahan masukan bagi semua guru agar dapat menggunakan model pembelajaran kooperatif tipe think pair share pada saat mengajar guna meningkatkan hasil belajar siswa khususnya pada mata pelajaran Bahasa Indonesia supaya dapat terlaksana dengan maksimal.

3. Sebagai bahan masukan bagi sekolah untuk menggunakan model pembelajaran kooperatif tipe think pair share dengan materi percakapan karena telah terbukti meningkatkan hasil belajar siswa kelas V SD Negeri 104273 Cilawan Kecamatan Pantai Cermin T.P 2017/2018.

4. Bagi peneliti selanjutnya kiranya hasil penelitian tindakan kelas ini dapat dijadikan suatu model pembelajaran dalam pengajaran serta pengetahuan untuk menambah wawasan dan pemahaman mengenai penggunaan model pembelajaran dalam proses belajar mengajar.

\section{DAFTAR PUSTAKA}

Aqib, Zainal, Dkk. 2015. Penelitian Tindakan Kelas untuk Guru SD,SLB,dan TK. Bandung: Yrama Widya.

Dimyati dan Mudjono. 2013. Belajar dan Pembelajaran. Jakarta: Rineka Cipta. Hamalik, Oemar. 2013. Kurikulum dan Pembelajaran. Jakarta: Bumi Aksara. 
Istarani. 2012. 58 Model Pembelajaran Inovatif. Medan: Media Persada. Istarani, Pulungan Intan. 2015. Ensiklopedi Pendidikan. Medan: Larispa.

Jihad, Asep dan Abdul Haris. 2013. Evaluasi Pembelajaran. Yogyakarta: Multi Pressindo.

Kurniasih, Imas dan Sani Berlin. 2016. Ragam Pengembangan Model Pembelajaran untuk Peningkatan Profesionalitas Guru. Yogyakarta: Kata Pena.

Purwanto. 2014. Evaluasi Hasil Belajar. Yogyakarta: Pustaka Pelajar.

Rusman. 2014. Model-model Pembelajaran. Jakarta: PT Raja Grafindo Persada.

Sagala, Syaiful. 2013. Konsep dan Makna Pembelajaran. Bandung: Alfabeta. Sahertian, Piet A. 2010. Konsep Dasar dan Teknik Supervisi Pendidikan dalam Rangka Pengembangan Sumber Daya Manusia. Jakarta: Rineka Cipta.

Sanjaya, Wina. 2011. Strategi Pembelajaran Berorientasi Standar Proses Pendidikan. Jakarta: Kencana Perdana Media.

Shoimin, Aris. 2016. 68 Model Pembelajaran Motivatif dalam Kurikulum 2013. Yogyakarta: Ar-Ruzz Media.

Slameto. 2013. Belajar dan Faktor-Faktor yang Mempengaruhi. Jakarta: Rineka Cipta.

Sugiono. 2015. Metode Penelitian Pendekatan Kuantitatif, Kualitatif dan R\&D. Bandung: Alfabeta.

Suprijono, Agus. 2010. Cooperative Learning. Yogyakarta : Pustaka Belajar.

Susanto, Ahmad. 2010. Cooperative Learning. Jakarta: Rineka Cipta.

Syah, Muhibbin. 2015. Psikologi Pendidikan. Bandung: PT Remaja Rosda Karya.

Tampubolon, Saur. 2014. Penelitian Tindakan Kelas. Jakarta: Erlangga.Trianto. 2011. Mendesain Model Pembelajaran Inovatif-Progresif. Jakarta: Kencana. 